\title{
PENYELESAIAN SENGKETA HUBUNGAN KERJA DI KOTA MAKASSAR
}

\author{
Muhammad Hasyim \\ Universitas Sawerigading Makassar
}

\begin{abstract}
Respondents' personal backgrounds that stated the effective use of litigation institutions to settle work disputes came from judges at the Makassar District Court, some employees from the Makassar City Manpower Office, some employers, all union/bad organization organizers, advocates and workers who had and is having a work dispute. Respondent's personal background stating ineffective or ineffective use of litigation institutions to resolve work disputes, are those who partly come from Makassar City Manpower Office employees, especially for those in charge of work disputes, as well as some from employers who have been declared defeated through a work court ruling. In addition to these dependent factors, it turns out that conflicts that occur in the work can also be caused due to the large influence of independent factors (indicators) whose indicators consist of legal structure, legal substance, legal culture and the level of legal awareness of each party involved. have an interest. Based on empirical data collected during the research, it is known that in general the background of the causes of work cases in Makassar City, during the period from 2004 to 2008 was more dominantly influenced by independent factors rather than dependent factors.T.
\end{abstract}

Keywords: Disputes, Settlement, Work Relations.

\begin{abstract}
Abstrak
Latar belakang pribadi responden yang menyatakan efektif penggunaan lembaga litigasi menyelesaikan perselisihan kerja berasal dari unsur hakim pada Pengadilan Negeri Makassar, sebagian pegawai dari Kantor Dinas Tenaga Kerja Kota Makassar, sebagian pengusaha, keseluruhan pengurus organisasi serikat kerja/buruk, dan advokat serta pekerja yang pernah dan sedang mengalami perselisihan kerja. latar belakang pribadi responden yang menyatakan kurang efektif dan/atau tidak efektif penggunaan lembaga litigasi menyelesaikan perselisihan kerja, adalah mereka yang sebagian berasal dari kalangan pegawai Kantor Dinas Tenaga Kerja Kota Makassar, terutama bagi mereka yang membidangi masalah-masalah perselisihan kerja, serta sebagian dari kalangan pengusaha yang pernah dinyatakan kalah melalui putusan pengadilan kerja. Di samping faktor-faktor dependen tersebut, ternyata konflik yang terjadi dalam kerja dapat pula disebabkan karena besarnya pengaruh dari faktor-faktor independen (bebas) yang indikatornya terdiri dari struktur hukum, substansi hukum, kultur hukum dan tingkat kesadaran hukum dari masing-masing pihak yang


berkepentingan. Berdasarkan data empirik yang berhasil dihimpun selama berlangsungnya penelitian, diketahui bahwa pada umumnya latar belakang penyebab terjadinya kasus-kasus kerja di Kota Makassar, selama kurun waktu dari tahun 2004 sampai dengan tahun 2008 lebih dominan dipengaruhi oleh faktor independen daripada faktor dependen.

Kata Kunci : Hubungan Kerja, Penyelesaian, Sengketa.

\section{PENDAHULUAN}

Sebagaimana dalam Undang-Undang Dasar Negara RI 1945 pada pasal 28 D ayat (2) ditegaskan, bahwa setiap orang berhak untuk bekerja serta mendapat imbalan dan perlakuan yang adil dan layak dalam hubungan kerja. Hubungan kerja dimaksud, lebih dikenal dengan Kerja yang secara dogmatig dan normatif diatur lebih lanjut dalam Undang-Undang (UU) Nomor 13 Tahun 2003 tentang Ketenagakerjaan. Pada Bab XI mulai dari pasal 102 sampai dengan pasal 149 berisi norma hukum mengenai Kerja, sedang pada Bab XII mulai dari pasal 140 sampai dengan pasal 172 mengenai Pemutusan Hubungan Kerja.

Selanjutnya di dalam Undang-Undang Nomor 2 Tahun 2004 telah diatur secara eksplisit tata cara dan prosedur penyelesaian perselisihan Kerja, baik melalui peran aktif lembaga Bipatrit agar Perselisihan Kerja secara musyawarah untuk mencapai mufakat, Konsiliasi dan Arbitrase maupun gugat-menggugat dengan memberdayakan Badan Peradilan Umum sebagai institusi indipenden yang menyelenggarakan kekuasaan kehakiman sebagaimana dimaksud dalam Undang-undang Nomor 8 Tahun 2004 yang telah merubah dan menyempurnakan Undang-Undang Nomor 2 Tahun 1986 tentang Peradilan Umum.

Kemudian secara empiris masih banyak kasus-kasus Perselisihan Kerja yang dibiarkan berlangsung secara alami (natural), tanpa memanfaatkan saluran hukum yang telah disediakan dalam rangka Penyelesaian Perselisihan Kerja. Di lain sisi lembaga Bipatrit, Tripatrit dan Administrasi Negara tidak atau kurang pro-aktif memberikan bantuan kepada tenaga kerja yang bersangkutan disebabkan adanya pengaruh dari faktor internal, misalnya tenaga kerja menganggap dirinya sebagai pihak yang lemah atau karena tidak mengetahui hak dan kewajiban dalam suatu Kerja, sedang pengaruh dari faktor eksternal seperti kedudukan strata sosial dan kekuatan ekonomi pengusaha yang sering dimanfaatkan untuk menekan para tenaga kerja.

Kemudian sebagai salah satu indikasi tidak atau belum terjaminnya hak-hak pekerja pada setiap kasus-kasus Pemutusan Hubungan Kerja, antara lain sebagai berikut : 
1. Undang-Undang Nomor 13 Tahun 2003 tidak secara tegas mencantumkan sanksi hukum terhadap pelaksanaan Pasal 156 ayat (2), (3) dan (4) dalam rangka perlindungan pekerja.

2. Substansi Pasal 156 ayat (2) UU Nomor 13 Tahun 2003, tidak tegas mengatur masalah uang pesangon. Hal ini disebabkan substansi hukum yang rumusannya menggunakan kata paling sedikit, sehingga dimungkinkan tidak efektifnya penyelesaian hak pekerja atas risiko Pemutusan Hubungan Kerja.

3. Sebagian besar perusahaan baik dalam bentuk Badan Usaha Milik Negara (BUMN), maupun Badan Usaha Milik Daerah (BUMD), dan perusahaanperusahaan swasta diduga keras belum mempersiapkan cadangan dana Pemutusan Hubungan Kerja ataupun pensiun. Fenomena yang demikian, akan menjadi beban berat apabila terjadi Pemutusan Hubungan Kerja.

Berkenaan latar belakang kondisi dan fenomena-fenomena sosial di atas, menuntut peran aktif Pemerintah (Pusat dan Daerah) untuk segera mungkin menetapkan kebijaksanaan yang bersifat strategis dalam mencari dan menemukan sistem atau cara yang lebih efektif dan diharapkan dapat menjamin kepastian terbayarnya hak-hak finansial pekerja yang terkena kasus Pemutusan Hubungan Kerja.

Di samping itu, eksistensi dan keberadaan Hakim Adhoc pada Pengadilan Kerja yang berasal dari unsur Serikat Pekerja/Buruh dan Pengusaha (Apindo) masih perlu dipertanyakan, karena produk hukum yang diciptakan dalam bentuk putusan Pengadilan Kerja masih sering mendapat pengaruh atau intervensi dari pihak-pihak tertentu, sehingga amat putusannya tidak mengandung nilai-nilai keadilan.

Sehubungan dengan hal tersebut, fenomena-fenomena sosial dimaksud menjadi motivasi untuk dilakukan penelitian dan hasil penelitian dituangkan dalam suatu karya ilmiah berjudul : Penyelesaian sengketa Hubungan Kerja di Kota Makassar.

\section{METODE PENELITIAN}

Penelitian ini dilaksanakan di Kota Makassar, Perusahaan yang menjalin kerja, dan di tempat kediaman tenaga kerja yang sedang dan/atau telah mengalami perselisihan kerja. Penetapan pelaksanaan penelitian diharapkan dapat memperoleh informasi dan masukan serta data yang bersifat normatif dan empiris berkenaan dengan UU Nomor 2 Tahun 2004 dalam rangka menyelesaikan perselisihan kerja di Kota Makassar. 
Populasi responden dalam penelitian ini yakni masyarakat yang ada di Kota Makassar utamanya pada tenaga kerja yang ada di perusahaan. Adapun sampel dilakukan secara random sebanyak 20 responden yang dianggap sudah dapat mewakili kepentingan hukum dari keseluruhan populasi.

\section{PEMBAHASAN}

\section{A. Bentuk penyelesaian sengketa hubungan kerja di Kota Makassar.}

Berbagai usaha dan upaya telah dilakukan Kantor Dinas Tenaga Kerja Kota Makassar, dalam rangka mengantisipasi segala kemungkinan terjadinya perselisihan kerja, seperti mengadakan pertemuan secara berkala dengan para pengusaha dan serikat pengusaha, pekerja dan serikat pekerja/buruh. Namun usaha dan upaya positif dimaksud, belum berhasil meniadakan fenomenafenomena sosial yang dapat menghindari terjadinya benturan di antara pekerja dan pengusaha. Akan tetapi terhadap fenomena-fenomena sosial dimaksud, justru menjadi pemicu dan penyebab terjadinya perselisihan kerja.

Perselisihan kerja yang terjadi di Kota Makassar, tidak hanya menimpa perusahaan-perusahaan yang memperkerjakan tenaga kerja dalam jumlah dan skala besar, akan tetapi dapat pula merambah pada perusahaan-perusahaan yang tergolong menengah dan kecil.

Kantor Dinas Tenaga Kerja Kota Makassar, telah memprogramkan untuk melaksanakan pengawasan dan pembinaan, serta penyuluhan hukum dan sosialisasi terhadap berbagai peraturan perundang-undangan ketenagakerjaan pada setiap triwulan. Dana penyuluhan hukum dan sosialisasi peraturan perundangundangan ketenagakerjaan, keseluruhannya dianggarkan bersumber dari Anggaran Pendapatan dan Belanja Pemerintah Kota Makassar.

Di samping itu, Kantor Dinas Tenaga Kerja Kota Makassar tetap berupaya semaksimal mungkin untuk menjalin hubungan kerja sama dengan para pengusaha dan serikat pengusaha, maupun terhadap pekerja dan beberapa organisasi serikat pekerja/buruh. Hubungan kerja sam dimaksud, lebih berorientasi pada peningkatan kinerja dan produktivitas hasil kerja sebagaimana diamanahkan Undang-Undang Nomor 13 Tahun 2003 Juncto Undang-Undang Nomor 2 Tahun 2004.

Sehubungan dengan perbedaan kepentingan di antara para pihak inilah sehingga tidak dapat dihindari kemungkinan terjadinya kasus-kasus perselisihan kerja, dan di antara kasus-kasus perselisihan kerja yang terjadi di Kota Makassar.

Penyelesaian perbedaan penafsiran tentang hak-hak normatif pekerja melalui forum musyawarah untuk mufakat dilaksanakan oleh lembaga bipatrit, sebagai langkah awal atau tahap pertama dari suatu penyelesaian perselisihan kerja. 
Kasus-kasus perselisihan kerja yang berhasil ditangani dan diselesaikan oleh lembaga bipatrit, adalah kasus-kasus yang sifatnya tidak terlalu signifikan.

Perbedaan penafsiran terhadap hak-hak normatif pekerja dimaksud, sehingga menjadi perselisihan kerja. Perselisihan ini tidak berhasil (gagal) diselesaikan secara langsung atau suka rela oleh lembaga Bipatrit, sehingga ditingkatkan penyelesaiannya pada Kantor Dinas Tenaga Kerja Kota Makassar melalui lembaga mediasi, arbitrase dan konsiliasi. Namun hasilnyapun dianggap gagal sehingga atas rekomendasi pasal 5 UU Nomor 2 Tahun 2004, diselesaikan melalui bantuan badan peradilan yang dalam hal ini dilaksanakan dan diselesaikan oleh pengadilan kerja.

\section{B. Penyelesaian Kasus Kerja}

Sebagaimana telah dikemukakan pada bagian terdahulu, bahwa Negara Republik Indonesia adalah negara hukum maka secara ex officio tindakan main hakim sendiri yang didasarkan atas kesewenang-wenangan merupakan perbuatan yang bertentangan dengan hukum. Untuk mengantisipasi tindakan main hakim sendiri, pemerintah membentuk beberapa lembaga pelaksana dan penegak hukum yang diharapkan dapat membantu pencari keadilan, terutama bagi pekerja yang merasa dirugikan akibat dari tindakan pengusaha.

Berkenaan dengan hal tersebut, maka sistem hukum yang berlaku di Indonesia, secara tegas tidak dibenarkannya tindakan main hakim sendiri (eigenrichting). Tidak adanya alasan pembenar bagi tindakan main hakim sendiri, karena eksistensi Eigenrichting tergolong perbuatan melanggar hukum.

Sistem hukum yang berlaku di Indonesia, bahwa setiap terjadi perbedaan penafsiran menyebabkan terjadinya perselisihan kerja, maka penyelesaiannya harus melalui tata cara dan prosedur yang diatur secara limitatif dalam pasal 3, 4 dan 5 UU Nomor 2 tahun 2004.

Masih tingginya minat masyarakat yang terlibat langsung kasus perselisihan kerja menggunakan lembaga litigasi menyelesaikan permasalahan hukumnya, disebabkan keterlibatan pihak ketiga (hakim karier) yang dianggap lebih independen dan sama sekali tidak mempunyai kepentingan dalam menyelesaikan setiap kasus perselisihan kerja. Lain halnya dengan penggunaan lembaga non litigasi, seperti Bipatrit, Konsiliasi, Arbitrase dan Mediator masih melibatkan salah satu unsur dari para pihak yang berselisih, sehingga keputusannya pun dianggap tidak atau belum adil.

Adapun latar belakang pribadi responden yang menyatakan efektif penggunaan lembaga litigasi menyelesaikan perselisihan kerja berasal dari unsur hakim pada Pengadilan Negeri Makassar, sebagian pegawai dari Kantor Dinas 
Tenaga Kerja Kota Makassar, sebagian pengusaha, keseluruhan pengurus organisasi serikat kerja/buruk, dan advokat serta pekerja yang pernah dan sedang mengalami perselisihan kerja.

Kemudian latar belakang pribadi responden yang menyatakan kurang efektif dan/atau tidak efektif penggunaan lembaga litigasi menyelesaikan perselisihan kerja, adalah mereka yang sebagian berasal dari kalangan pegawai Kantor Dinas Tenaga Kerja Kota Makassar, terutama bagi mereka yang membidangi masalahmasalah perselisihan kerja, serta sebagian dari kalangan pengusaha yang pernah dinyatakan kalah melalui putusan pengadilan kerja.

Walaupun ada beberapa kelemahan pengadilan kerja sebagai lembaga litigasi yang dikemukakan oleh kedua responden sebagai alasan penolakan keberadaan lembaga litigasi dimaksud, namun keduanya secara jujur dan transparan mengakui bahwa keputusan pengadilan kerja jauh lebih adil daripada keputusan lembaga non litigasi.

Sebagaimana telah dikemukakan pada bagian terdahulu, bahwa pelaksanaan norma dan kaidah hukum yang diatur dalam peraturan perundang-undangan tidaklah semudah membalikkan kedua telapak tangan. Norma dan kaidah hukum yang diatur dalam peraturan perundang-undangan, karena sebaik dan serapi manapun untaian kata menjadi kalimat hukum sering menimbulkan perbedaan penafsiran di antara para pihak yang berkepentingan. Apabila terhadap suatu norma dan kaidah hukum menimbulkan penafsiran yang berbeda di antara para pihak yang berkepentingan, maka secara ex officio akan menjadi akar masalah timbulnya perselisihan.

Demikian pula halnya dengan peraturan perundang-undangan yang mengatur ketenagakerjaan atau kerja, apabila analisis dari teori-teori konflik yang bermuara pada sebab-akibat (causaliteit) khususnya Theory Conditio Sine Qua Non (von buri), maka terjadinya ketidakseimbangan dalam pelaksanaan kerja dapat mempengaruhi keadaan kondusif di antara pekerja atau serikat kerja/buruh dengan perusahaan atau serikat pengusaha. Keadaan yang tidak kondusif dimaksud, dapat mempengaruhi produktivitas kerja dan produktivitas usaha sehingga diperlukan tindakan dan kebijakan yang dapat menetralisir suasana. Namun tindakan dan kebijakan tersebut, justru menjadi salah satu faktor dependen (terikat) penyebab terjadinya kasus-kasus perselisihan hak, perselisihan kepentingan, perselisihan pemutusan hubungan kerja, maupun perselisihan antar serikat pekerja/buruh.

Di samping faktor-faktor dependen tersebut, ternyata konflik yang terjadi dalam kerja dapat pula disebabkan karena besarnya pengaruh dari faktor-faktor independen (bebas) yang indikatornya terdiri dari struktur hukum, substansi 
hukum, kultur hukum dan tingkat kesadaran hukum dari masing-masing pihak yang berkepentingan.

Berdasarkan data empirik yang berhasil dihimpun selama berlangsungnya penelitian, diketahui bahwa pada umumnya latar belakang penyebab terjadinya kasus-kasus kerja di Kota Makassar, selama kurun waktu dari tahun 2004 sampai dengan tahun 2008 lebih dominan dipengaruhi oleh faktor independen daripada faktor dependen.

Apabila hasil penilaian responden melalui jawaban kuesioner dipertautkan dengan teori-teori konflik yang bermuara pada sebab-akibat (causaliteit), maka menurut pandangan Von Buri sebagai penggagas Theory Conditio Sine Qua Non, pengaruh substansi hukumlah yang secara umum dipandang sebagai penyebab terjadinya kasus-kasus perselisihan kerja selama kurun waktu dari tahun 2004 sampai dengan tahun 2008 di Kota Makassar.

\section{PENUTUP}

\section{A. Kesimpulan}

Berdasarkan pembahasan diatas maka, disimpulkan sebagai berikut :

1) Penyelesaian kasus kerja menurut Undang-undang Nomor 2 Tahun 2004 di Kota Makassar Kurang Efektif.

2) Kurang efektifnya kasus penyelesaian perselisihan kerja di kota Makassar disebabkan faktor dependen yaitu perselisihan hak, perselisihan kepentingan, perselisihan PHK dan perselisihan antar serikat pekerja/serikat buruh serta faktor independen yakni struktur hukum, substansi hukum, kultur hukum dan kesadaran hukum.

\section{B.Saran -Saran}

1) Pemerintah perlu meninjau kembali undang-undang Nomor 13 tahun 2003 untuk diadakan perbaikan dan penyempurnaan. Sekaligus mensinerjikan dengan norma hukum yang diatur dalam Undang-Undang Nomor 2 Tahun 2004. Kemudian norma hukum yang diatur di dalamnya tidak menimbulkan penafsiran hukum yang dapat menjadi biang keladi terjadinya perselisihan kerja, lalu lebih mengeftifkan pemberdayaan lembaga litigasi melalui pengadilan kerja dalam rangka penyelesaian kasus-kasus perselisihan kerja di Kota Makassar, sehingga norma hukum tersebut, dapat dilaksanakan sebagaimana seharusnya.

2) Pemerintah perlu lebih meningkatkan pelaksanaan pengawasan kerja, terutama pengawasan terhadap norma hukum yang diatur dalam peraturan perusahaan, perjanjian kerja maupun terhadap perjanjian kerja bersama, sehingga dapat mengantisipasi segala kemungkinan timbulnya kasus-kasus 
perselisihan kerja di Kota Makassar. Hal ini dimaksudkan agar penyelesaian kasus Kerja dapat lebih efektif. 


\section{DAFTAR PUSTAKA}

Abdulkadir Muhammad. Hukum Acara Perdata Indonesia. Bandung: Alumni, 1996.

Achmad Ali. Menguak Tabir Hukum (Suatu Kajian Filosofis dan Sosiologis). Jakarta, Candra Parata, 1996. 1998.

Menjelajahi Kajian Empiris terhadap Hukum. Jakarta: Watampone,

Peranan Pengadilan Sebagai Pranata Sosial; Suatu Tinjauan Sosiologi Hukum (Pidato Pengukuhan Guru Besar Tetap Ilmu Hukum UNHAS). Makassar: Universitas Hasanuddin, 1999.

Anonim. Undang-Undang Nomor 13 Tahun 2003 tentang Ketenagakerjaan. Jakarta, departemen Tenaga kerja dan Transmigrasi Republik Indonesia, 2003.

. Undang-Undang Republik Indonesia Nomor 2 Tahun 2004 tentang Penyelesaian Perselisihan Kerja. Jakarta: Asosiasi Kerja Indonesia, 2004.

Himpunan Peraturan Perundang-Undangan; Pembentukan Peraturan Perundang-undangan; Undang-Undang Nomor 10 tahun 2004. Bandung: Fokus media, 2004.

Djazuli Bachar. Eksekusi Putusan Perkara Perdata; segi hukum dan penegakan Hukum. Jakarta: Akademika Presindo, 1997.

Johan M. Echols dan Hassan Shadly. Kamus Inggris Indonesia. Jakarta: Gramedia, 2001.

Kansil, C.S.T dan Christine S.T. Kansil dan Engeline R. Palandeng. Konstitusikonstitusi Indonesia tahun 1945-2000. Jakarta: Pustaka Sinar harapan, 2001.

Kartasapoetra, G dan Rience G. Widianingsih. Pokok-pokok Hukum Perburuhan. Bandung: Armic, 1992.

Kuffal, H.M.A. Himpunan Sembilan Undang-Undang: Kekuasaan Kehakiman, Mahkamah Agung, Mahkamah Konstitusi, Kejaksaan Republik Indonesia, Kepolisian negara republi Indonesia, Peradilan Umum, Peradilan Hak Azasi Manusia, Komisi Kebenaran dan Rekonsiliasi, Komisi Yudisial. Malang: Universitas Muhammadiyah, 2005.

Moeltano. Azas-azas Hukum Pidana. Jakarta: Bian Aksara, 1997.

Mohd. Syaufi Syamsuddin. Hukum Acara Penyelesaian Perselisihan Kerja. Jakarta: Sarana Bhakti Persada, 2005.

Muchtar A. Kamaruddin. Hukum Jaminan Sosial; Menelaah Hakikat dan Pemberdayaan Jaminan Sosial tenaga kerja Harian di Indonesia. Makassar: Umitoha Ukhuwah grafika, 2002.

Muzni Tambusai. Peranan dan Fungsi Mediator, Arbiter dan Konsiliator Menurut UU Nomor 2 Tahun 2004. Jakarta: Direktur jenderal 
Pembinaan Kerja - departemen Tenaga kerja dan Transmigrasi Republik Indonesia, 2004.

Poerwadarminta, W J.S. Kamus Umum Bahasa Indonesia. Jakarta: Balai Pustaka, 1996.

Retnowulan Sutantio dan Iskandar Oeripkartawinata. Hukum Acara Perdata Dalam Teori dan praktek. Bandung: Alumni, 1996.

Satjipto Rahardjo. Ilmu Hukum. Bandung: Alumni, 1996.

Soerjono Soekanto. Tata Cara penyusunan Karya Tulis Ilmiah Bidang Hukum. Jakarta: Ghalia Indonesia, 1993. 